УДК 82.09

ББК $83 \cdot 3(\mathrm{O})+85 \cdot 374 \cdot 3(7 \mathrm{Coe})$

ОКТЯБРЬСКАЯ ГАРБО:

КЛАССИЧЕСКИЙ ГОЛЛИВУД

И РЕВОЛЮЦИЯ

\author{
(c) 2017 г. Т. Юкич \\ Загребский университет, \\ Загреб, Хорватия \\ Дата поступления статьи: 8 апреля 2016 г. \\ Дата публикации: 25 июня 2017 г.
}

DOI: IO.22455/2500-4247-20I7-2-2-56-63

Данное исследование было поддержано

Хорватским Научным Фондом.

Аннотация. В статье рассматривается попытка Эрнста Любича приспособить свой фильм «Ниночка» (I939) с Гретой Гарбой к образу Гарбо в роли советской революционерки; тем самым, учитывая огромную важность Гарбо для классического Голливуда, Октябрьская революция помещается в самый центр американского кинематографа того времени. Одновременно показывается, как пресловутая кинематографическая меланхолия Гарбо включает в себя остаточные для революций структуры аффекта. Более того, выбирая жанр комедии вместо мелодрамы, Любич выносит особую, связанную с революционной меланхолией, психополитику за пределы жанровых конвенций и делает ее конститутивной для кинематографа как такового. Наконец, в статье рассматривается, как Любич использует русскую литературу, в особенности «Анну Каренину» Л.Н. Толстого, как особую кодирующую систему, неотъемлемую от голливудской иконичности.

Ключевые слова: Эрнст Любич, фильм, революция, социализм, классический Голливуд, Л.Н. Толстой.

Информация об авторе: Татьяна Юкич - PhD по филологии, профессор Загребского университета; факультет гуманитарных и социальных наук. Ivana Lučića 3, Iоoоo. Загреб, Хорватия.

E-mail: tjukic@ffzg.hr 


\title{
THE OCTOBER GARBO: \\ CLASSICAL HOLLYWOOD \\ AND THE REVOLUTION
}

This is an open access article distributed under the Creative Commons Attribution 4.0 International (CC BY 4.0)

\author{
(C) 20I7. T. Jukić \\ University of Zagreb, \\ Zagreb, Croatia \\ Received: April 8, 2016 \\ Date of publication: June 25,2017
}

Acknowledgements: The research for this essay was supported by funding from the Croatian Science Foundation.

Abstract: I propose to discuss Ernst Lubitsch's decision to tailor Ninotchka (1939), his film with Greta Garbo, to Garbo in the role of a Soviet revolutionary, which - given the overwhelming importance of Garbo to classical Hollywood - is how the October Revolution is situated at the heart of American cinema at the time while Garbo's proverbial cinematic melancholia is shown to entail the structures of affect residual to revolutions. Moreover, by divorcing Garbo's revolutionary melancholia from melodrama and attaching it to comedy, Lubitsch extricates this particular psychopolitics from the fact of genre, now as an insight into the construction of film. Finally, I show how Lubitsch engages Russian literature, especially Tolstoy's Anna Karenina, as a code-holder for Hollywood iconicity.

Keywords: Ernst Lubitsch, film, revolution, socialism, classical Hollywood, Leo Tolstoy.

Information about the author: Tatjana Jukić, $\mathrm{PhD}$ in Philology, Professor, Faculty of $\mathrm{Hu}-$ manities and Social Sciences, University of Zagreb, Ivana Lučića 3, Ioooo Zagreb, Croatia.

E-mail: tjukic@ffzg.hr 
In 1939 Ernst Lubitsch, one of the most important authors of classical Hollywood, directed Ninotchka, a romantic comedy with Greta Garbo cast as a Soviet bureaucrat inordinately attached to the idea of the revolution. Indeed, the comedy derives its humor and its coherence from the fact that Ninotchka remains dedicated to the revolution even after everybody else's sense of politics has shifted and mutated, and even after she herself has abandoned her initial strict bureaucratic socialism. Put differently, the story of the film depends on Ninotchka's remaining a communist and a revolutionary in the world where the revolution, even in socialism, has become visible only in the traces of its betrayal.

This is how Ninotchka is fundamentally about betrayal: because the betrayal of the revolution coincides in Lubitsch with the betrayal of Garbo, insofar as Garbo remains alone and solitary in the world of his comedy as its only true revolutionary - others may end up loving her, but do not share her revolution. The Lubitsch Garbo thus corresponds to the Garbo who proved definitive to classical Hollywood precisely as a figure of betrayal, melodramatic abandonment and melancholia. In turn, Lubitsch suggests that melancholia may be the only configuration of affect to which revolution is residual, which is why Garbo may be the only functional point of departure to accessing the revolution in the cinema of classical Hollywood. Ultimately, this implies that revolution endures in Hollywood in the positions where Garbo proved indispensable to its symbolic core - the indispensability corroborated, succinctly, by the fact that Garbo was commonly referred to as divine.

That the narrative of Ninotchka was related structurally to Garbo can be evinced from the fact that the film was tailored to her. James Harvey reports that, 
after leaving Paramount in 1938, Lubitsch began working on The Shop Around the Corner, to be produced by the independent company he founded with Myron Selznick. However, the new company never took off, and MetroGoldwynMayer, at the request of their star, Greta Garbo, offered to produce The Shop for Lubitsch on the condition that he first made Ninotchka for them, with Garbo. In November I938 Lubitsch signed a contract with MGM, for two films, and began filming The Shop three months after having completed Ninotchka [5, c. 382, 383, 392 $]^{\mathrm{I}}$.

Given that Garbo herself invited Lubitsch to direct her, she evidently saw him as the paramount authority on things cinematic, likely to provide an insight into her as the icon of classical Hollywood and, by extension, into the constitution of Hollywood iconicity. Also, her invitation suggests that her earlier films failed to articulate consistently the semiosis that she generated for Hollywood. Symptomatically, those earlier films were melodramas and Garbo was their staple as the Hollywood's most famous melancholic; Lubitsch, on the other hand, was famous for his musicals and comedies. A Lubitsch comedy was therefore clearly intended as a vehicle to a kind of cinematic psychoanalysis, with a task to explore Garbo's generic unhappiness or, more precisely, to explore her unhappiness as a-generic, as a complex with a meaning to and of itself. That this concern informed the project from its inception can be deduced from a detail noted by James Harvey, about the slogan with which Ninotchka was advertised: "According to some accounts, the whole project began with 'Garbo laughs!': once they had the slogan, they looked for a movie to go with it” $[5, \text { c. } 384]^{2}$. In this light, Ninotchka reads actually as a specimen story of classical Hollywood, just as the Oedipus myth has been described as the specimen story of psychoanalysis, with the revolution being to Lubitsch what the Oedipus complex was to Freud3.

The story opens with three Soviet trade delegates who arrive in Paris, in order to arrange the sale of the jewels confiscated by the Soviet authorities from

\footnotetext{
I Lubitsch visited the Soviet Union in 1936, at the invitation of the Soviet government [5, c. 375$]$.

2 "Garbo laughs!" was a rejoinder to "Garbo talks!", the slogan used to advertise Anna Christie (I930), Garbo’s first talkie: Garbo's breakthrough into comedy was compared to her breakthrough into speech.

3 See [4] about the Oedipus myth as the specimen story of psychoanalysis. It is in this sense that Ninotchka reads also as a film in which the Oedipal structures of classical Hollywood are deconstructed, insofar as classical Hollywood relied staunchly on its genres.
} 
the Grand Duchess Swana (Ina Claire), now residing in Paris. Swana intervenes into the sale and claims the jewels, hoping to secure a financial settlement with the Soviets. Even before her intervention, however, it is clear that the three delegates want to prolong their stay in Paris and enjoy, as long as possible, the luxuries inaccessible in socialism. Ninotchka, a special envoy, is sent from Moscow to sort out the affair. Unlike her comrades, she is not susceptible to luxury but is strict in her disciplined state socialism; indeed, she comes off as a socialist masochist, and signals that state socialism may be understood as an ideology based in masochism. Yet, before the deal has been closed, Ninotchka succumbs to temptation: she falls in love with Count Leon d'Algout (Melvyn Douglas), Swana's kept man, whom she initially perceives as weak and frivolous but good for disengaged sex. Swana takes advantage of Ninotchka's weakness by first stealing the jewels and then making Ninotchka an offer she cannot refuse: if Ninotchka wants to regain the jewels, which are to feed the hungry Russian people, she must abandon Leon and return to Moscow. No longer laughing, Ninotchka accepts the terms, returns to Moscow and relapses into the proverbial, melancholy Garbo.

This is how Lubitsch's cinematic intelligence comes to the fore: the climax of his comedy hinges on the proposition that the laughing Garbo is not at a remove from the melancholy Garbo, but partakes of her. Garbo's melancholia is thereby exposed as a-generic: as a structure of affect that is constituent to cinematic visuality, not merely to a genre. This is in line with Roland Barthes' remark in Mythologies [1, c. 67], when Barthes says that Garbo is of the order of concept, whereas Audrey Hepburn, for instance, is of the order of an event. Significantly, Lubitsch's Garbo depends on revisiting the meaning and the logic of the revolution if she is to make sense of her condition.

It is at this point that Lubitsch introduces a distinction crucial equally to his narrative and to his Garbo, the one between state socialism and the revolution: it turns out that the melancholy Ninotchka remains at one with the logic of the revolution, but can no longer embrace the script of state socialism. Put differently, Lubitsch's Garbo climaxes in the position where her melancholia is shown to incorporate the crisis which is integral to revolutions; the problem with state socialism, it turns out, is that it cannot maintain the revolutionary crisis, even as it acknowledges revolution as its rationale. Also, Lubitsch hints that masochism may be the script which explains how the melancholia of the revolution is ultimately couched in the socialism of the postrevolutionary state. 
That this problem was central to Lubitsch can be evinced from the setup of the scene in which Ninotchka explains herself to Commissar Razinin, her cold and unyielding boss. Razinin's bureaucratic statism reciprocates Ninotchka's own initial strictness, and serves to emphasize the critical distinction that she has come to appreciate, the one between the irreducible crisis of the revolution and the raison d'État of state socialism. Lubitsch cast Bela Lugosi, the proverbial Hollywood vampire, as Razinin, as if to suggest that state socialism was vampire-like compared to the melancholia of the revolution - that state socialism fed on the revolution like a vampire. Moreover, Garbo's explaining her melancholia to Lugosi is a wry joke on the Hollywood studio system: when Ninotchka implores Razinin to let her work herself to death in the rhythms of her melancholia, because this is how she is productive to the state, this comes across as Garbo explaining her melancholy self as profitable to Hollywood, with Lugosi alternating between the roles of a Soviet functionary and a Hollywood producer. Hollywood too, Lubitsch seems to imply, fed on the melancholy Garbo like a vampire. Indeed, Lubitsch's invention of a Garbo who laughs, of Garbo as a comedienne, effectively eliminated Garbo from Hollywood: she made only one more film (Two-Faced Woman with George Cukor, in I94I), and then withdrew from film, to spend the rest of her life in seclusion.

Interestingly, Lubitsch suggests that the meaning of Garbo, not only the meaning of Ninotchka, resides in the memory regimes and the structures of affect that Hollywood imported from Russian culture. Anna Karenina, the melodrama directed by Clarence Brown in I935, with Garbo as Karenina, is crucial in this context. Lubitsch constructed his Ninotchka around Garbo's earlier Anna Karenina, so that Ninotchka was operative actually in the positions where she repeated and mutated the structures of Tolstoy's novel as it had been translated into the Hollywood melodrama.

Central to Tolstoy is the narrative pattern organized around Anna's entrances and exits: she enters the novel when she steps off the train in Moscow, only to exit in the same way, when she tools up the train into an instrument of (narrative) suicide. The same device remains central to Brown's melodrama: the Hollywood Anna Karenina depends for its coherence on the majestic close up of Garbo as she enters the Moscow railway station (and the narrative), which is also how the terms of her exit are anticipated ${ }^{4}$. Similarly, Ninotchka enters the

4 In his discussion of Hollywood melodrama Stanley Cavell argues that train sequences entail a comment on the very logic of film; also, he finds Garbo central to his discussion of Hollywood melodrama [3, c. $397 ; 2$, c. 2]. 
film when she steps off the Moscow train. Yet, her recognition by Lubitsch's camera is significantly deferred, and she is granted a close up only after a delay, just as there is nothing majestic about her entrance: instead of a Garbo whose face is framed in luxurious fur for a close up in the opening sequences of Anna Karenina, Lubitsch's Garbo is markedly austere, lackluster and ascetic. A similar mutation affects her exit. Like Anna, Ninotchka exits by regressing to the terms of her arrival: she is sent off, again, to sort out yet another business deal botched by the Soviet trade delegates. Paris as destination is now replaced by Constantinople, just as Ninotchka is no longer traveling by train but by plane; nonetheless, the idea of transport persists in Lubitsch as it does in Anna Karenina, signaling in both cases a curious transport between life and death. To be sure, there is no suicide in Ninotchka, but Lubitsch does imply that melancholia, to which Ninotchka is reduced as she arrives in Constantinople, incorporates the logic of suicide: that there is an aspect to melancholia more threatening than the prospect of suicide. As a result, when Ninotchka learns that her mission to Constantinople was secretly arranged by Leon in order to secure their reunion, the happy end thus achieved remains overshadowed by the threat, and translates into an upsetting structure of sacrifice and resurrection. Moreover, it is as she exits that Garbo receives from Lubitsch the spectacular close-up and the luxurious fur to frame her face, the set-up which introduced her as Anna Karenina into the Brown film: as if to signal that Garbo could not promise closure, only revolutionary sacrifices.

Another proposition should be addressed here, pertinent equally to Lubitsch's film and to Tolstoy's novel. While Tolstoy relies on contrasting the stories of Anna Karenina and Konstantin Levin, so that melancholy Anna provides a counterpart to Levin's unrelenting engagement with political economy, subjectivity and sexuality, Lubitsch fuses the narratives of Anna Karenina and of Levin, so that melancholy Ninotchka keeps echoing Levin's (and Tolstoy's) preoccupations with the political economy specific to Russian rurality: Ninotchka argues, insistently, for a socialist physiocracy - for a political economy that takes into

5 The threat associated with suicide persists in Lubitsch's films. It surfaces in The Shop when Clara Novak (Margaret Sullavan) is enveloped into an intricate metonymic network of suicide-cum-melancholia, just as it affects the actress Maria Tura (Carole Lombard) of To Be or Not to Be, insofar as she cannot escape the trappings of the roles of Ofelia, Gertrude and Lady Macbeth. Alenka Zupančič notes that a similar threat is associated with Jennifer Jones in Cluny Brown (I946), the last film Lubitsch saw to completion [6, c. I79]. 
account the conditions specific to Soviet agriculture and its peasantry. Consequently, Anna and Levin, instead of departing in different narrative directions, are imagined by Lubitsch in terms of narrative confluence. This is how Lubitsch suggests in fact that Tolstoy's novel has anticipated the structures, as well as the impasses, of the Soviet state socialism. In other words, Ninotchka reads as Lubitsch's rewrite of Anna Karenina, in which Anna serves to translate Levin's concerns into an implacable and irredeemable political crisis.

That Lubitsch was fascinated with Tolstoy's novel and perceived it as a key to the films he made at the time can also be inferred from his explicit references to Anna Karenina in The Shop Around the Corner (1940) and To Be or Not to Be (1942). Tolstoy's novel surfaces in both these films as a code-holder or a cipher-container, in the climactic instances when the films depend on setting up the channels of communication that are invisible to strangers and enemies. Tellingly, while Lubitsch explores socialism in Ninotchka, he approaches capitalism from a similar angle in The Shop Around the Corner, whereas To Be or Not to Be is an acute insight into Nazism. By mobilizing Tolstoy as an analytic lynchpin, in all these films, Lubitsch suggests in fact that the three films constitute a trilogy, just as Tolstoy's literature is thereby promoted into a code-holder and a cipher-container for classical Hollywood. Finally, it is symptomatic that Tolstoy became formulaic to Lubitsch in his films of the early I940s, in the positions where visibility itself was perceived in terms of implacable crisis and distress, as if signaling that the revolutionary agenda of classical Hollywood mutated, inevitably perhaps, into the semiosis of world war.

\section{References}

I Barthes R. Mythologies. Paris, Éditions du Seuil, I957. 24I p. (In French)

2 Cavell S. Contesting Tears. The Hollywood Melodrama of the Unknown Woman. Chicago, London, The University of Chicago Press, I996. 255 p. (In English)

3 Cavell S. Cities of Words. Pedagogical Letters on a Register of Moral Life. Cambridge (Mass.), London, Harvard University Press, 2004. 458 p. (In English)

$4 \quad$ Felman S. Beyond Oedipus: The Specimen Story of Psychoanalysis. Modern Language Notes, I983, no 98.5, pp. I02I-I053. (In English)

5 Harvey J. Romantic Comedy in Hollywood. From Lubitsch to Sturges. New York, Da Capo Press, I998. 716 p. (In English)

6 Zupančič A. Kaj je ‘Cluny Brown’? Zadeva Lubitsch. Eds. Ivana Novak, Jela Krečič. Ljubljana, Slovenska kinoteka, Društvo za teoretsko psihoanalizo, 20I3. S. I67-I79. (In Slovenian) 